\title{
Assessment of Soybean Resistance Level to Pod Sucking Bug Riptortus linearis F. (Hemiptera: Coreidae) based on No-choice and Free-choice Tests
}

\author{
A. Krisnawati, K. Noerwijati, S.W. Indiati, Trustinah, E. Yusnawan, M.M. Adie
}

10.18805/LRF-650

\begin{abstract}
Background: The infestation of the pod sucking bug Riptortus linearis is one of the limiting factors of soybean productivity in Indonesia. The research aims were to identify the level of resistance to the pod sucking bug $R$. linearis on several soybean genotypes based on the no-choice test (NCT) and free-choice tests (FCT).

Methods: The genetic materials used were 49 soybean genotypes. The study was conducted in the Indonesian Legumes and Tuber Crops Research Institute (ILETRI) from August to December 2020, using the randomized block design in triplicates. The evaluation for pod sucking bug resistance was based on NCT and FCT.

Result: The FCT resulted in two genotypes with a consistent moderately resistance level (20-40\% of damage intensity) to pod sucking bug based on the pod and seed damage intensity. The NCT method resulted in five genotypes as moderately resistant (20-40\% of damage intensity) to pod sucking bug based on the seed damage. The NCT resulted in higher average intensity of pod and seed damage $(80.25 \%$ and $71.23 \%$, respectively) than the FCT $(69.91 \%$ and $69.09 \%$, respectively). Two soybean genotypes (Degra/Anjasmoro1-559 and Anjasmoro/IAC100-2-618) with a consistent moderately resistance level could be used for cultivar improvement in the breeding program. The pod trichome density was suggested to be one of the effective morphological defenses against the pod sucking bug attack.
\end{abstract}

Key words: Correlation analysis, Cultivar improvement, Pod damage, Seed damage, Trichome density.

\section{INTRODUCTION}

Riptortus linearis is a pod-sucking pest commonly found in the tropics, as well as a threat to soybean farming in subtropical areas. The damage caused by the infestation of $R$. linearis is one of the causes of suboptimal soybean productivity in Indonesia. This pest is considered more important than other pod pest complexes because it has a wider spread throughout soybean growing seasons and its attacks occur from the beginning of seed filling until pod maturation (Asadi et al. 2012; Indiati et al. 2017). The yield loss due to $R$. linearis attack was from negligible to significant (Krisnawati and Adie 2019; Li et al. 2021), depend on the developmental stage of plant at the time of attack, planting date, the plant resistance level (Asadi et al. 2012; Abudulai, 2018). Pod sucking bugs cause economic damage by reducing the ability of seeds to grow, decreasing grain quality and yield, decreasing seed vigor due to tissue damage caused by seed puncture and delaying plant maturation (Leonard et al. 2011).

The highest attack intensity of $R$. linearis occurred during the pod filling phase which caused the highest yield losses (Sarjan et al. 2021). Similarly, the mid to late pod filling phase (R5-R7) was reported as the peak of stink bug Nezara viridula (L.) infestation in soybean (Baur et al. 2000). Pod borer pests, such as $N$. viridula, R. linearis, Etiella zinckenella and Leptocorisa acuta, were found to be responsible for $18.26 \%$ of pod damage in the soybean field in Sulawesi, Indonesia (Rahayu et al. 2018). Meanwhile, in Southern Brazil, the green-belly stink bug has been reported
Indonesian Legume and Tuber Crops Research Institute, Jl. Raya Kendalpayak Km 8, PO Box 66 Malang 65101, East Java, Indonesia.

Corresponding Author: A. Krisnawati, Indonesian Legume and Tuber Crops Research Institute, JI. Raya Kendalpayak Km 8, PO Box 66 Malang 65101, East Java, Indonesia.

Email: aydakrisnawati@pertanian.go.id

How to cite this article: Krisnawati, A., Noerwijati, K., Indiati, S.W., Trustinah, Yusnawan, E. and Adie, M.M. (2022). Assessment of Soybean Resistance Level to Pod Sucking Bug Riptortus linearis F. (Hemiptera: Coreidae) based on No-choice and Free-choice Tests. Legume Research. 45(1): 90-96. DOI: 10.18805/LRF-650.

Submitted: 26-08-2021 Accepted: 11-11-2021 Online: 05-01-2022

as a threat to the cultivation of a variety of crops, including soybean (Smaniotto and Panizzi, 2015).

Various approaches are used to prevent crop loss due to pod sucking pests, but the most common is the use of insecticides, both chemical and botanical (Traore et al. 2019; Seetharamu et al. 2020; Agale et al. 2021). Nevertheless, the use of a resistant variety of pod sucking bug is an important alternative to reduce the negative impact of inappropriate use of insecticides. A screening of soybean resistance for stink bug ( $N$. viridula L.) in Indonesia has obtained three resistant varieties and it was also shown that pests favor varieties with a short reproductive phase followed by small seed sizes as a source of food (Kuswantoro et al. 2020). Asadi et al. (2012) obtained two resistant soybean 
genotypes which its resistance was controlled by two recessive genes located at different loci with epistatic dominant interaction. Another study found a genotype with resistant reaction to pod sucking bug $R$. linearis (Krisnawati and Adie, 2018). The availability of several soybean genotypes resistant to pod sucking bugs, then the efforts to increase soybean resistance to these pests were considered to have a high chance of success.

Varietal screening is a continual process that improves the probability of finding resistant genotypes. No-choice and free-choice tests are the most commonly used methods for determining resistance (Pinheiro et al. 2005; Van Driesche and Murray, 2004). Therefore, the research aims were to assess the level of resistance to the pod sucking bug $R$. linearis on several soybean genotypes based on the nochoice and free-choice tests.

\section{MATERIALS AND METHODS}

\section{Research materials}

The genetic materials used were 49 soybean genotypes which consists of 42 crossing lines, six improved varieties (Detap 1, ljen, Derap 1, Dega 1, Anjasmoro and Gema) and one genotype resistant to pod sucking bug $(\mathrm{G} 100 \mathrm{H})$.

\section{Study area}

This study was conducted in the Indonesian Legumes and Tuber Crops Research Institute (ILETRI) which is located at Malang (East Java, Indonesia), from August to December 2020. The experiments were conducted in the screen house and laboratory of ILETRI. The pod sucking bugs $R$. linearis were collected from soybean fields at Kendalpayak Research Station (Malang) and reared in the Laboratory of Breeding, ILETRI. The insect pests used in this study were the first offspring (F1) of $R$. linearis imago resulted from the rearing.

\section{Planting and experimental design}

Soybean genotypes for no-choice and free-choice tests were grown in the screen house of ILETRI. The experiment was arranged in a Randomized Block Design in triplicates. Each genotype was planted in a plastic pot $(\Phi=18 \mathrm{~cm})$ with $10 \mathrm{~kg}$ of soil mixed with manure (4:1 ratio), two plants per pot. Planting was done in such a way that ten soybean genotypes could flower at the same period. Before sowing, $5 \mathrm{~g}$ of NPK fertilizers were applied per pot. Pests and diseases were optimally controlled only until 30 days after planting (dap). The evaluation for pod sucking bug resistance was based on the no-choice test and free-choice tests.

\section{No-choice test (NCT)}

When plants reached the R5 stage, each soybean genotype was enclosed in a cage (height $=50 \mathrm{~cm}$, diameter $=26 \mathrm{~cm}$ ) made of nylon netting (with replicates for each). Then, each cage was infested with a pair of newly emerged adult $R$. linearis.

\section{Free-choice-test (FCT)}

All soybean genotypes were enclosed in cage in a large nylon mesh cage (length $=120 \mathrm{~cm}$, width $=120 \mathrm{~cm}$ and height $100 \mathrm{~cm}$ ) and arranged in a random order according to replication. Hence, there were three nylon mesh cages represent the number of replications. The newly emerged adults $R$. linearis were infested to each mesh cage when plants reached the R5 stage ( $\mathrm{n}=2$ per plant or 98 adults $R$. linearis per cage).

\section{Observation}

Soybean pods were harvested once they had reached full maturity (R8 stage). Soybean pods were visually observed under a binocular microscope for the number of punctures on seed caused by the $R$. linearis attack and the average trichome density in $4 \mathrm{~mm}^{2}$ from the adaxial and abaxial surface of leaflets of each genotype. The observation was also made for the number of attacked pods and seeds and the percentage of pod and seed damage. The following formula is used to calculate the percentage of pods and seeds damage by $R$. linearis:

$$
\begin{aligned}
& \text { Pod damage intensity }(\%)=\frac{\sum \text { Attacked pods }}{\sum \text { Total pods }} \times 100 \% \\
& \text { Seed damage intensity }(\%)=\frac{\sum \text { Attacked seeds }}{\sum \text { Total seeds }} \times 100 \%
\end{aligned}
$$

The soybean resistance to pod sucking bugs based on seed and pod damage was classified as follows: resistant $(<21 \%)$, moderately resistant $(21-40 \%)$, moderately susceptible (41-60\%), susceptible $(61-80 \%)$ and highly susceptible (>80\%) (Asadi et al. 2012).

\section{Data analysis}

The descriptive statistic was used for all observed data. The correlation analysis was performed among the observed data using the Pearson correlation analysis (Singh and Chaudhary, 1977) and visualized using the Corrplot and Hmisc packages of the RStudio program version 1.3.959 (RStudio Team, 2020).

\section{RESULTS AND DISCUSSION}

The grouping of resistance levels based on the nochoice test

The evaluation of soybean resistance against $R$. linearis using no-choice test (NCT) showed the range of pod damage intensity of 49 soybean genotypes was $54.78-100 \%$ (an average of $80.25 \%$ ) and the range of seed damage intensity was $23.91-100 \%$ (an average of $71.23 \%$ ) (Fig 1). The average intensity of the pod damage was higher than the seed damage. Previous studies found the similar result to those found in this study (Krisnawati et al. 2016; Maulidah, 2006; Krisnawati and Adie, 2018).

Fig 2 showed the grouping of the level of resistance of 49 genotypes to $R$. linearis based on the pod and seed damage intensity in the NCT. There were no soybean genotypes classified as resistant or moderately resistant based on the pod damage intensity in the NCT. However, two genotypes were classified as moderately susceptible, 24 genotypes were susceptible and 23 genotypes were 
highly susceptible. Based on the seed damage intensity, it also did not find a resistant genotype, but five genotypes were found to be moderately resistant, namely Grobogan/ G100H-12-369, Grobogan/Degra-20-762, Degra/Grob-2257, Ijen and $\mathrm{G} 100 \mathrm{H}$. No-choice tests are regarded to maximize the expression of host range (Van Driesche and Murray 2004) and also particularly useful for determining choosiness (Charalabidis et al. 2017) since it does not provide the opportunity for insect pests to select the preferred host. Thus, it caused a high average intensity of damaged on seed as well as pod.

The grouping of resistance levels based on the freechoice test

In the free-choice test (FCT), the pod damage intensity of 49 soybean genotypes was ranged from $25.97-100 \%$ (an average of $69.91 \%$ ) and the range of seed damage intensity was $32.62-100 \%$ (an average of $69.09 \%$ ) (Fig 3). It can be seen that the average damage intensity of seed and pod in the FCT is comparable. Nevertheless, pod and seed damaged intensity was influenced by genotypes. A previous study in the non-controlled environment showed the range of the intensity of pod and seed damage was $34.46-76.82 \%$

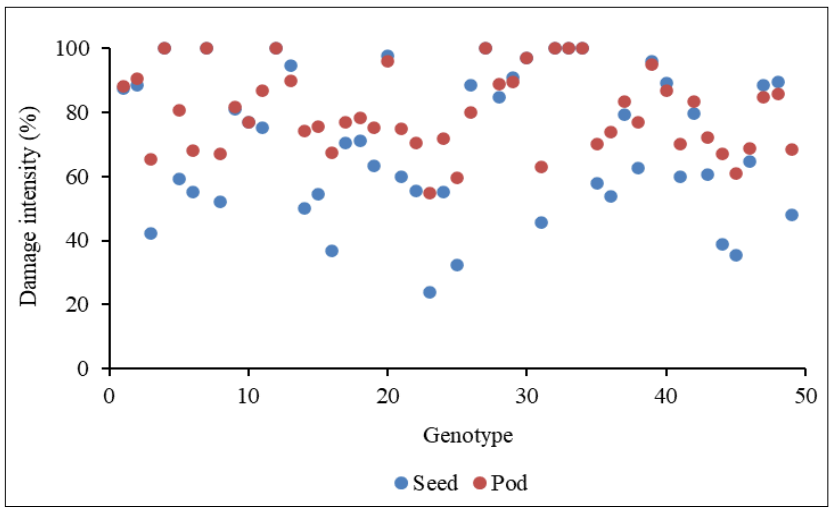

Fig 1: The pod and seed damage intensity of 49 soybean genotypes in the no-choice test (NCT).

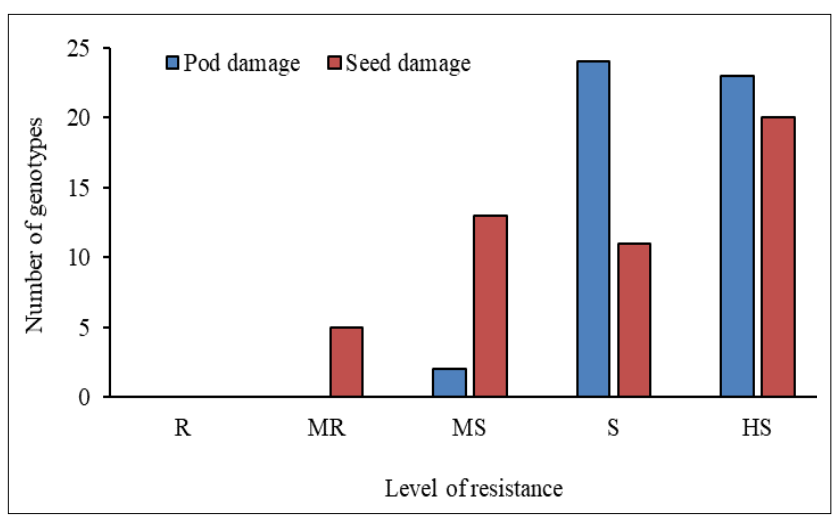

Fig 2: The level of resistance of 49 soybean genotypes based on the pod and seed damage intensity in the no-choice test (NCT).

$\mathrm{R}=$ Resistant, $\mathrm{MR}=$ Moderately resistant, $\mathrm{MS}=$ Moderately

susceptible, $\mathrm{S}=$ Susceptible, HS= Highly susceptible. (an average of $60.16 \%$ ) and $11.72-42.31 \%$ (an average of $23.08 \%$ ), respectively (Krisnawati and Adie, 2018).

The grouping of the level of resistance of 49 genotypes to $R$. linearis based on the pod and seed damage intensity in the FCT was presented in Fig 4. The classification of resistance to $R$. linearis based on the pod as well as seed damage intensity in the FCT resulted in a similar result (Fig 4). The difference number of genotypes was slightly different for the susceptible and highly susceptible groups. There were no resistant soybean genotypes have been found based on the classification of pod damage as well as the seed damage intensity. However, two genotypes (Degra/ Anjasmoro-1-559 and Anjasmoro/IAC100-2-618) were identified with a consistent resistance level (moderately resistant) based on the pod and seed damage intensity.

The resistance evaluation using the FCT method was to provide an opportunity for $R$. linearis imago to make a host selection of 49 soybean genotypes. Naturally, insect pests have the ability to choose the preferred food source (Mainali et al. 2014). As a result, the two genotypes reported in this study with a consistent moderately resistant level suggested that these genotypes were not preferred as a food source for $R$. linearis, or indicating the occurrence of

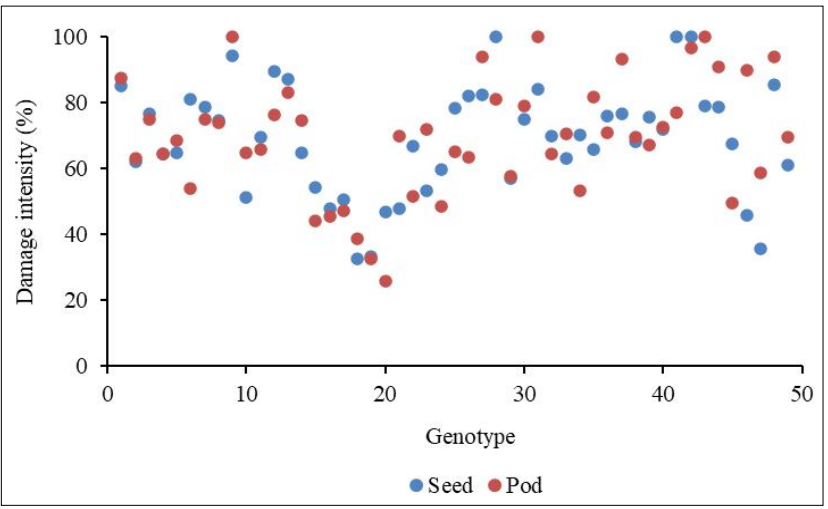

Fig 3: The pod and seed damage intensity of 49 soybean genotypes in the free-choice test (FCT).

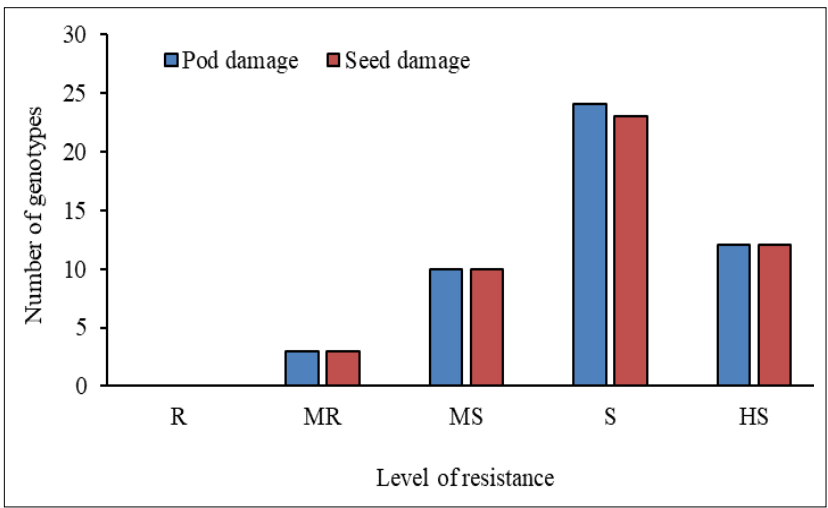

Fig 4: The level of resistance of 49 soybean genotypes based on the pod and seed damage intensity in the free-choice test (FCT). $\mathrm{R}=$ Resistant, $\mathrm{MR}=$ Moderately resistant, $\mathrm{MS}=$ Moderately susceptible, $S=$ Susceptible, HS= Highly susceptible. 
non-preference mechanism on those genotypes. A previous study found a soybean genotype (G511H/Anj//Anj-2-8) which showed a consistent resistance to pod sucking bug $R$. linearis based on the field evaluation in the controlled as well as the non-controlled environment (Krisnawati and Adie, 2018). A study by Kim and Lim (2010) found that pod sucking bug $R$. pedestris preferred Cheongjakong soybean variety to Daewonkong or Agakong variety in the choice-test. In cowpea, Olatunde et al. (2007) reported that the genotype of IT86D-716 was resistant to the pod sucking bug (Clavigralla tomentosicollis) and its resistance exhibited both non-preference and antibiosis resistance mechanisms.

Soybean resistance evaluation based on the FCT revealed a lower average of damage intensity than those based on the NCT, both in terms of pod and seed damage. According to several studies, one of the phenotypic features of resistant genotype to the insect pests was a lower ratio of pod damage (Santos et al. 2018; Kuswantoro et al. 2020). Krisnawati et al. (2016) used the NCT method to investigate soybean resistance to $R$. linearis and found one consistent resistant genotype based on the pod and seed damage. The NCT approach was also used to identify soybean resistance to armyworm pests, but it was found that no soybean genotypes were classified as resistant (Bayu et al. 2017). Nevertheless, the use of NTC in the resistance evaluation was suggested will produce genotypes with higher resistance to pod-sucking pests (Krisnawati et al. 2017).

\section{Number of punctures on seed}

Seed damage is a direct result of $R$. linearis attack on soybeans. The number of punctures on the seeds varied between soybean genotypes (Fig 5). The average number of punctures in the seeds in the FCT ranged from 0.32 to 5.93 punctures (an average of 2.69 punctures/seed), while the number of punctures in the seeds in the NCT ranged from 1.26 to 8.29 punctures (an average of 4.73 punctures/ seed). The difference in the number of punctures seed could be caused by the presence of volatile compounds that are unfavorable to the insects (Ulhoa et al. 2020) or pod morphological characteristic which inhibits feeding behavior, indicating the expression of feeding non-preference as a mechanism of resistance (War et al. 2012). Another study suggests that the number of punctures on seed were stimulated by the first prick to taste (Souza et al. 2013), or maybe related to a physical factor such as the distance between the seed and the wall of the pod, preventing the stylet of the pod sucking bug from reaching the seed (Pannizi and Silva, 2009) and also in the different thickness of the soybean pod wall (Rahman and Lim, 2017) and different depth of stylet penetration into the pod tissue (Esquivel, 2015).

In this study, the number of punctures on seed in the NCT was higher than in the FCT, this suggested that despite the previously mentioned factors, each individual plant in the NCT experienced more attacking pressure due to insects were given no-choice access to make host selection. The seed damage caused by pod-sucking pest will reduce the soybean seed vigor and quality and also the yield productivity per unit area (Bae et al. 2014).

\section{The pod trichome density}

The trichome density on the soybean pod of 49 genotypes varied from 29-179 trichomes/4 $\mathrm{mm}^{2}$ with an average of 81 trichomes $/ 4 \mathrm{~mm}^{2}$ (Fig 6). Twelve genotypes have trichome density over 100 trichomes $/ 4 \mathrm{~mm}^{2}$, suggested those genotypes have relatively dense trichomes. A previous study on the 150 soybean genotypes by Adie and Krisnawati (2017) obtain the trichome density of 150 ranged from 1259 trichomes $/ 4 \mathrm{~mm}^{2}$ with an average of 27.64 trichomes $/ 4$ $\mathrm{mm}^{2}$ with 66 genotypes exhibited a higher trichome density than the average density. Trichomes have been reported to protect plants from insect pests (Jat et al. 2021). A dense layer of trichomes acts as a physical barrier to insects feeding (Karabourniotis et al. 2020).

\section{Correlation analysis}

The correlation study among observed traits was presented in Fig 7. The correlation between the damage intensity among resistance evaluation methods (NCT and FCT) showing a positively significant correlation. The relationship between trichome density and the intensity of $R$. linearis attack in the NCT revealed that the trichome density had a non-significant correlation with the pod damage $\left(r=-0.245^{\mathrm{ns}}\right)$

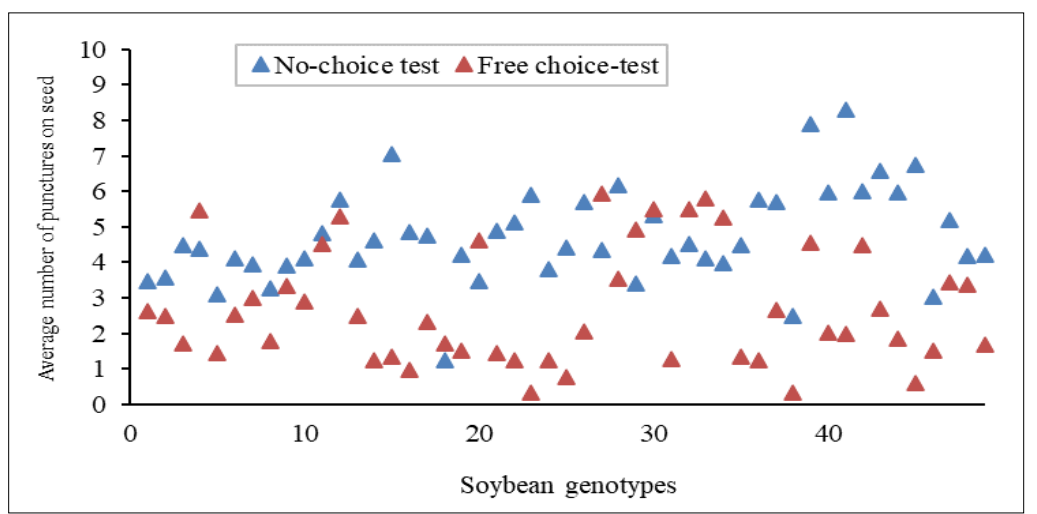

Fig 5: The average number of punctures on seed of 49 soybean genotypes in the no-choice test (NCT) and free choice-test (FCT). 


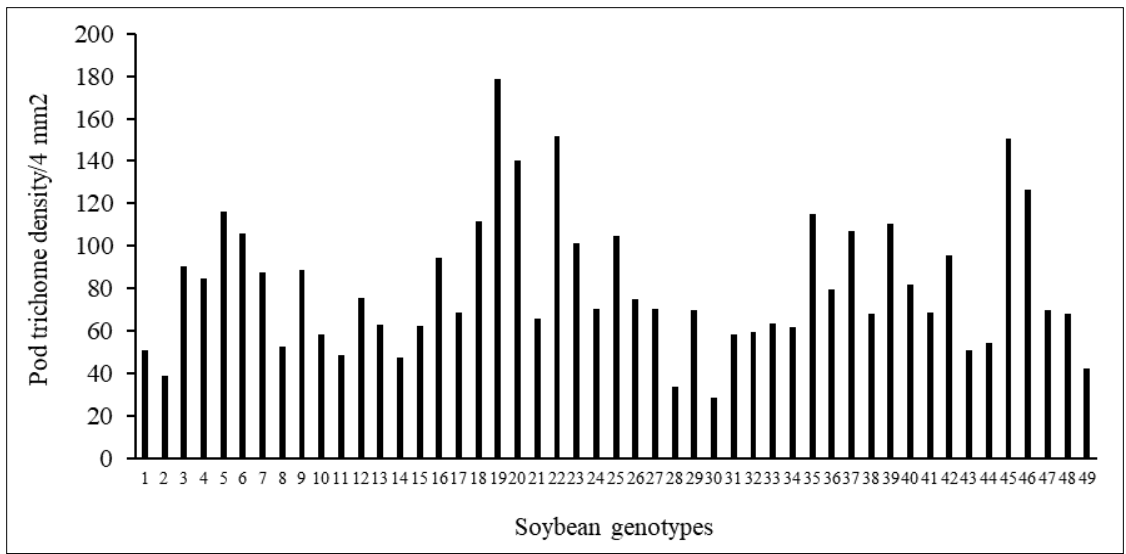

Fig 6: Pod trichome density of 49 soybean genotypes.

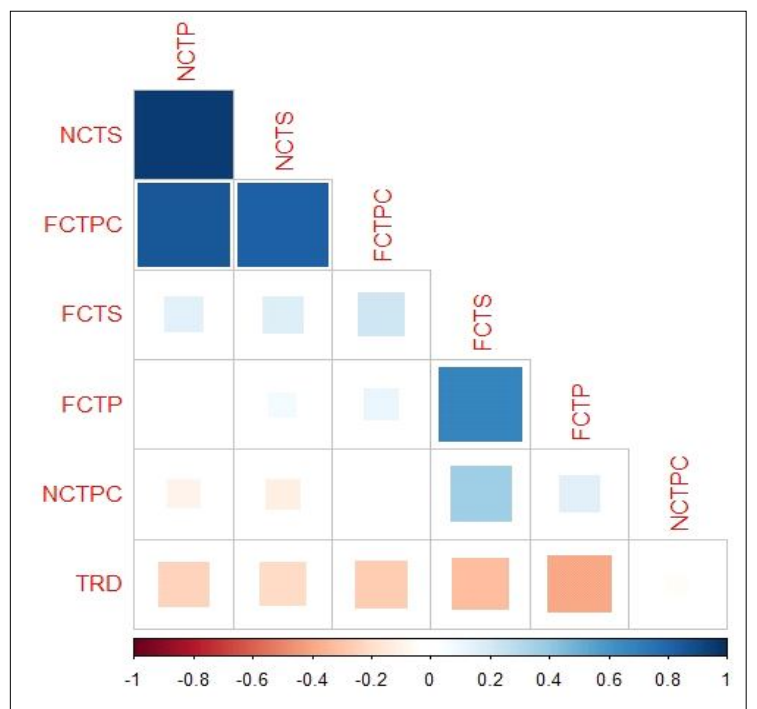

Fig 7: Correlation analysis among observed traits.

The darker the color, the higher the correlation between the two traits, with significant correlation is $< \pm 0.05$. (NCTS= Seed damage in the no-choice test, NCTP= Pod damage in the no-choice test, FCTS = Seed damage in the free-choice test, FCTP= Pod damage in the free-choice test, NCTPC $=$ Number of punctures on seed in the no-choice test, FCTPC= Number of punctures on seed in the free-choice test, $\mathrm{TRD}=$ Trichome density/4 $\mathrm{mm}^{2}$ ).

as well as the seed damage $\left(r=-0.218^{\text {ns }}\right)$. However, in the FCT, the trichome density had a negatively significant correlation with the pod damage $\left(r=-0.394^{* *}\right)$ and seed damage $\left(r=-0.324^{\star}\right)$. In the NCT, insect pests were forced to feed, thus the trichome density may not play a significant role in the plant defense. In addition to genetic factors, the plant resistance could be due to the other morphological factors (antixenosis or non-preference) as well as antibiosis factors (Smith, 2005; War et al. 2012).

In this study, in the FCT, the denser trichome caused a lower pod as well as seed damage intensity. This suggests that pod trichomes play an important role in plant defense by reducing insect interactions with pods. Denser and longer trichomes on pods, as well as harder pod shells, act as a physical barrier in soybean antixenosis resistance to the pod sucking bug (Suharsono and Sulistyowati, 2012; War et al. 2012). In the behavioral studies of $R$. pedestris, the dense hairiness of mature soybean pods might also inhibit the movements of the bugs (Rahman and Lim, 2017).

\section{CONCLUSION}

Based on pod and seed damage intensity, the FCT produced two genotypes with a constant moderately resistance level (20-40\% of damage intensity) to pod sucking bug. Based on seed damage, the NCT identified five genotypes as moderately resistant to pod sucking bug (20-40\% damage intensity). The evaluation of soybean resistance against $R$. linearis using the NCT resulted in higher intensity of pod and seed damage than the FCT method. Two soybean genotypes (Degra/Anjasmoro-1-559 and Anjasmoro/ IAC100-2-618) with a consistent moderately resistance level could be used in the breeding program. Based on the correlation study, the pod trichome density was suggested to be effective for pod morphological defense against the pod sucking bug attack.

\section{ACKNOWLEDGEMENT}

This research was part of the National Research Priority Program by the Ministry of Research and Technology/ National Research and Innovation Agency and funded by the RISPRO Mandatory, Indonesia Endowment Fund for Education, Ministry of Finance, Republic of Indonesia, under Project No. 21/E1/PRN/2020.

\section{REFERENCES}

Abudulai, M. (2018). Influence of planting date and cultivar on pod-sucking bug infestation and yield of soybean in northern Ghana. Annals of Agricultural Sciences. 63: 77-81. doi: 10.1016/j.aoas.2018.05.004.

Adie, M.M. and Krisnawati, A. (2017). Variability of pod trichome and agronomic characters of several soybean genotypes. Biodiversitas. 18: 416-421. doi: 10.13057/biodiv/d180153. 
Agale, S.V., Gupta, R., Rangarao, G.V. and Wani, S.P. (2021). efficacy of some biopesticides against Helicoverpa armigera (Hubner) in pigeon pea under natural condition. Legume Research. 44: 463-471.

Asadi, Purwantoro, A. and Yakub, S. (2012). Genetic control of soybean resistance to soybean pod sucker (Riptortus linearis L.). Agrivita. 34: 28-35. doi: 10.17503/agrivita. v34i1.141.

Bae, S.D., Kim, H.J. and Mainali, B.P. (2014). Infestation of Riptortus pedestris (Fabricius) decreases the nutritional quality and germination potential of soybean seeds. Journal of AsiaPacific Entomology. 17: 477-481. doi: 10.1016/j.aspen. 2014.04.006.

Baur, M.E., Boethel, D.J., Boyd, M.L., Bowers, G.R., Way, M.O. and Heatherly, L.G. (2000). Arthropod populations in early soybean production systems in the mid-south. Environmental Entomology. 29: 312-328. doi: 10.1093/ee/29.2.312.

Bayu, M.S.Y.I., Krisnawati, A. and Adie, M.M. (2017). Response of Soybean Genotypes against Armyworm, Spodoptera litura based on No-choice Test. IOP Conference Series and Earth Environmental Science. 102: 012033. doi: 10.1088/1755-1315/102/1/012033.

Charalabidis, A., Dechaume-Moncharmont, F.X., Petit, S. and Bohan, D.A. (2017). Risk of predation makes foragers less choosy about their food. PloS ONE. 12(11): e0187167.

Esquivel, J.F. (2015). Stylet penetration estimates for a suite of phytophagous Hemipteran pests of row crops. Environmental Entomology. 44: 619-626. doi: 10.1093/ee/nvv027.

Indiati S.W., Bejo and Rahayu, M. (2017). Diversity of mung bean insect pests and their natural enemies in farmers' fields in East Java, Indonesia. Biodiversitas. 18: 1300-1307. doi: $10.13057 /$ biodiv/d180403.

Jat, B.L., Dahiya, K.K., Yadav, S.S. and Mandhania, S. (2021). Morpho physico-chemical components of resistance to pod borer, Helicoverpa armigera (Hübner) in pigeonpea [Cajanus cajan (L.) Millspaugh]. Legume Research. 44: 967-976.

Karabourniotis, G., Liakopoulos, G., Nikolopoulos, D. et al. (2020). Protective and defensive roles of non-glandular trichomes against multiple stresses: Structure-function coordination. Journal of Forestry Research. 31: 1-12. doi: 10.1007/ s11676-019-01034-4.

Kim, S. and Lim, U.T. (2010). New soybean variety, Agakong, as a host of Riptortus pedestris (Fabricius): Study on field occurrence and biological attributes in the laboratory. Journal of Asia-Pacific Entomology. 13: 261-265. doi: 10.1016/ j.aspen.2010.03.005.

Krisnawati, A. and Adie, M.M. (2018). Evaluation of soybean resistance to pod-sucking bug, Riptortus linearis F. and performance of its agronomic characters. Biosaintifika. 10: 213-222. doi: 10.15294/biosaintifika.v10i1.12806.

Krisnawati, A. and Adie, M.M. (2019). The resistance of soybean genotypes to the pod feeding insects. Planta Tropika: Journal of Agro Science. 7: 48-57. doi: 10.18196/pt.2019. 093.48-57

Krisnawati, A., Bayu, M.S.Y.I. and Adie, M.M. (2016). Identification of soybean resistance to pod sucking bug (Riptortus linearis) by no-choice test. Biosaintifika Journal of Biology and Biology Education. 8: 407-414.
Krisnawati, A., Bayu, M.S.Y.I. and Adie, M.M. (2017). Screening of soybean genotypes for resistance to pod sucking bug, Riptortus linearis. Nusantara Bioscience. 9: 181-187. doi: 10.13057/nusbiosci/n090213.

Kuswantoro, H., Mejaya, I.M.J. and Baliadi, Y. (2020). Determination of agronomical characters as the resistance attributes of twenty soybean varieties to stink bug (Nezara viridula L.). Agrivita. 42: 53-67. doi: 10.17503/agrivita.v42i1.2121.

Leonard, B.R., Boquet, D.J., Padgett, B., Davis, J.A., Schneider, R., Griffin, J.L., Valverde, R.A. and Levy, R.J. Jr. (2011). Soybean green plant malady contributing factors and mitigation. Louisiana Agriculture. 54: 32-34.

Li, W., Gao, Y., Hu, Y., Chen, J., Zhang, J. and Shi, S. (2021). Field cage assessment of feeding damage by Riptortus pedestris on soybeans in China. Insects. 12: 255. doi: 10.3390/insects 12030255 .

Mainali, B.P., Kim, H.J., Yoon, Y.N., Oh, I.S. and Bae, S.D. (2014). Evaluation of different leguminous seeds as food sources for the bean bug Riptortus pedestris. Journal of AsiaPacific Entomology. 17: 115-117. doi: 10.1016/j.aspen. 2013.11.007.

Maulidah, L. (2006). Character variability of soybean pod morphology [Glycine $\max$ (L.) Merrill] and its relation with their resistance to pod sucking bug Riptortus linearis F. Thesis, University of Muhammadiyah Malang. Malang, Indonesia.

Olatunde, G.O., Biobaku, I.A., Ojo, D.K., Pitan, O.O.R. and Adegbite, E.A. (2007). Inheritance of resistance in cowpea (Vigna unguiculata) to the pod-sucking bug Clavigralla tomentosicollis (Hemiptera: Coreidae). Tropical Science. 47: 128-133. doi: 10.1002/ts.206.

Panizzi, A.R. and Silva, F.A.C. (2009). Insects sucking seeds (Heteroptera). In: Bioecology and Insect Nutrition. [Panizzi, A.R., Parra, J.R.P. (Eds.)], Embrapa, Brasilia.

Pinheiro, J.B., Vello, N.A., Rossetto, C.J. and Zucchi, M.I. (2005). Potential of soybean genotypes as insect resistance sources. Crop Breeding and Applied Biotechnology. 5: 293-300.

Rahayu, M., Bande, L.O.S., Hasan, Yuswana, A. and Rinambo, F. (2018). Contribution of pod borer pests to soybean crop production (case in Pondidaha, Konawe District, Southeast Sulawesi). IOP Conference Series and Earth Environmental Science. 122: 012039. doi: 10.1088/1755-1315/122/1/ 012039.

Rahman, M.M. and Lim, U.T. (2017). Evaluation of mature soybean pods as a food source for two pod-sucking bugs, Riptortus pedestris (Hemiptera: Alydidae) and Halyomorpha halys (Hemiptera: Pentatomidae). PLoS ONE. 12: e0176187. doi: 10.1371/journal.pone.0176187.

RStudio Team. (2020). R: A language and environment for statistical computing. R Foundation for Statistical Computing, Vienna, Austria. https://www.R-project.org/.

Santos, M.D.F., Möller, M., Clough, S.J. and Pinheiro, J.B. (2018). Heritability of agronomic traits correlated with reduced stink bug damage in an $\mathrm{F}_{2 \cdot 3}$ soybean population derived from IAC-100. Journal of Crop Improvement. 32: 1-18. doi: 10.1080/15427528.2017.1370404. 
Sarjan, M., Fathiyani, B.D.S. and Yassi, A. (2021). Attack Intensity of Sucking Pods Insect Pest (Riptortus linearis) in Different Age of Soybean under Drought Stress Conditions. IOP Conference Series and Earth Environmental Science. 681: 012015. doi:10.1088/1755-1315/681/1/012015.

Seetharamu, P., Swathi, K., Dhurua, S., Suresh, M., Govindarao, S. and Sreesandhya, N. (2020). Bioefficacy of chemical insecticides against major sucking insect pests on grain legumes in India- A review. Legume Research. 43: 1-7. doi: $10.18805 / L R-4074$.

Singh, R.K. and Chaudhary, B.D. (1977). Biometrical Methods in Quantitative Genetic Analysis. Kalyani Publisher. India.

Smaniotto, L.F. and Panizzi, A.R. (2015). Interactions of selected species of stink bugs (Hemiptera: Heteroptera: Pentatomidae) from leguminous crops with plants in the Neotropics. Florida Entomologist. 98: 7-17. doi: 10.1653/024.098.0103.

Smith, C.M. (2005). Plant Resistance to Arthropods: Molecular and Conventional Approaches. Netherlands: Aa Dordrecht, Springer.

Souza, E.S., Baldin, E.L.L., da Silva, J.P.G.F. and Lourenção, A.L. (2013). Feeding preference of Nezara viridula (Hemiptera: Pentatomidae) and attractiveness of soybean genotypes. Chilean Journal of Agricultural Research. 73: 351-357. doi: 10.4067/S0718-58392013000400004.

Suharsono and Sulistyowati, L. (2012). Expression of resistance of soybean to the pod sucking bug Riptortus linearis $\mathrm{F}$. (Hemiptera: Coreidae). Agrivita. 34(1): 55-59. doi: 10.17 503/agrivita.v34i1.137.
Traore, F., Waongo, A., Sanou, A., Ba, M.N., Dabiré, C., Sanon, A. and Pittendrigh, B.R. (2019). Effects of cold- and hotpressed neem oil on eggs of the pod-sucking bug Clavigralla tomentosicollis Stål (Hemiptera:Coreidae) and its parasitoid Gryon fulviventre Crawford (Hymenoptera: Scelionidae) under laboratory conditions. African Entomology. 27: 395402. doi: $10.4001 / 003.027 .0395$.

Ulhoa, LA., Barrigossi, J.A.F., Borges, M., Laumann, R.A. and Blassioli-Moraes, M.C. (2020). Differential induction of volatiles in rice plants by two stink bug species influence behaviour of conspecifics and their natural enemy Telenomus podisi. Entomologia Experimentalis et Applicata. 168: 76-90. doi: 10.1111/eea.12869.

Van Driesche, R.G. and Murray, T.J. (2004). Overview of Testing Schemes and Designs Used to Estimate Host Ranges. In: Assessing Host Ranges for Parasitoids and Predators used in Classical Biological Control: A Guide to Best Practice. [Van Driesche R.G., Reardon R. (eds.)]. USDA Forest Service, Morgantown, West Virginia, USA.

War, A.R., Paulraj, M.G., Ahmad, T., Buhroo, A.A., Hussain, B., Ignacimuthu, S., Sharma, H.C. 2012. Mechanisms of plant defense against insect herbivores. Plant Signaling Behaviour. 7: 1306-1320. https://doi.org/10.4161/psb. 21663. 